\title{
Revestimentos a base de TEOS/ácido fosfônico como tratamento anticorrosivo para a liga AA2024-T3
}

\author{
TEOS/Phosphonic acid based coatings \\ as anticorrosive treatment \\ for AA2024-T3 alloy
}

Suelen Weimer Cendron ${ }^{1}$, Denise Schermann Azambuja ${ }^{2}$

\footnotetext{
${ }^{1}$ Instituto de Química - Universidade Federal do Rio Grande do Sul -UFRGS - Porto Alegre, RS e-mail: suu.cendron@hotmail.com

${ }^{2}$ Departamento de Físico-Química - Universidade Federal do Rio Grande do Sul -UFRGS-Porto Alegre, RS e-mail:denise@iq.ufrgs.br
}

\section{RESUMO}

O objetivo deste estudo foi investigar o comportamento corrosivo da liga de alumínio AA2024-T3 tratada com filmes obtidos pela combinação de tetraetilortossilicato (TEOS) com ODPA (ácido octadecilfosfônico) em solução de $\mathrm{NaCl}$ 0,05 mol L ${ }^{-1}$. As razões volumétricas de TEOS/etanol/água utilizadas foram 4:90:6 e 4:80:16, e os filmes formados foram denotados como 90TEOS e 80TEOS respectivamente. A adição de ácido fosfônico nos filmes TEOS foi testada como uma maneira de se obter um efeito cooperativo, a fim de melhorar as características de proteção do revestimento. Análises de espectroscopia de impedância electroquímica (EIE) e polarização potenciodinâmica mostraram que os filmes 90TEOS na presença de ODPA apresentaram um maior módulo de impedância após 168 horas de imersão em solução de cloreto. Os resultados obtidos indicam que os filmes obtidos apenas com TEOS não fornecem uma proteção adequada contra a corrosão, evidenciando a existência de sinergismo entre o ácido fosfônico e TEOS. Essa melhora foi relacionada à maior hidrofobicidade dos revestimentos.

Palavras chaves: Liga de Alumínio, Silano, Ácido fosfônico, EIE.

\section{ABSTRACT}

The aim of this study was to investigate the corrosion behavior of aluminum alloy AA2024-T3 substrates treated with self-assembled films obtained by combining tetraethylorthosilicate (TEOS) with ODPA (octadecylphosphonic acid)in a $0.05 \mathrm{~mol} \mathrm{~L}-1 \mathrm{NaCl}$ solution. The volumetric ratios of TEOS/ethanol/water used were 4:90:6 and 4:80:16, and the corresponding films formed were denoted as 90TEOS and 80TEOS, respectively. The addition of phosphonic acid to TEOS films was tested as a way to obtain a cooperative effect in order to improve the protective characteristics of the coating. Electrochemical impedance spectroscopy (EIS) and potentiodynamic polarization data showed that the 90 TEOS films in the presence of ODPA had the highest impedance modulus after $168 \mathrm{~h}$ of immersion in chloride solution. The results obtained indicate that undoped sol-gel coatings do not provide adequate protection against corrosion, evidenced by the existence of synergism between phosphonic acid and TEOS, improving the hydrophobicity of the films.

Keywords: Aluminum alloy, silane, phosphonic acid, EIS.

\section{INTRODUCION}

The aluminum alloy AA 2024-T3 is widely used as a fuselage skin and structural material in the aeronautics industry. However, this alloy has a high susceptibility to chemical attack and pitting corrosion, which is generally associated with the distribution and electrochemical properties of intermetallic compounds (IMCs) [1, 2]. In recent years, metal pre-treatments based on the formation of silane films have been developed to improve the corrosion resistance of metal substrates and the adhesion between metals and painted organic coatings $[3,4,5]$. 
Silanes are classified as self-assembling molecules (SAMs), representing an environmentally-friendly alternative to the classic protection systems based on chromates. A surface pre-treatment using SAM acts as a barrier preventing the corrosion of the metal $[3,5,6]$. However, this procedure confers a passive corrosion protection which can be damaged by aggressive species reaching the metallic substrate, leading to corrosion. The protection against active corrosion obtained in the presence of an inhibiting component in this pretreatment allows the corrosion rate to be minimized, preventing the degradation of the metal. Thus, a synergistic effect is obtained by using a silane layer modified with an inhibitor $[7,8,9,10]$

Recent studies have been carried out with the use of silanes in combination with inhibitors[11], bilayer systems where a silane coating precedes the epoxy paint [12] and epoxy coating systems which are modified with silanes [13].

The formation of SAMs on the aluminum substrate occurs when these compounds react spontaneously with $\mathrm{Al}_{2} \mathrm{O}_{3}$, producing a more hydrophobic layer on the metal surface $[6,14,15]$. Films based on TEOS/DTMS electrodeposited on AA2024-T3 alloy in the presence of cerium nitrate were studied by Zhang et. al [16]. Through the water contact angle analysis, the authors observed angles near to $160^{\circ}$ indicating the formation of superhydrofobic surfaces, which remains unchanged with the introduction of cerium. EIS analysis showed good results for the films in the presence of cerium salt. Recent studies in the literature involving inhibitors incorporation to TEOS films showed satisfactory results, improving anticorrosive properties [17, $18]$.

A comparative study of self-assembly monofunctional aliphatic molecules (phosphonic acids, thiols and carboxylic acid) on magnetron-sputtered aluminum was performed by Liakos et al[19]. The greater ability of the phosphonic acid head group was demonstrated, suggesting that greater coverage and order are attained with phosphonic acid. In recent studies, Dalmoro et al. investigated the effect of TEOS (tetraethoxyorthosilicate) modified with two phosphonic acids, ATMP (aminotrimethylenephosphonic acid) and EDTPO (1,2-diaminoethanetetrakis methylenephosphonic acid), on the corrosion behavior of the aluminum alloy AA 2024-T3, and demonstrated the enhanced protection obtained with EDTPO [20, 21].

It is well known that undoped TEOS films show high hydrophilicity and are not efficient for corrosion protection, requiring the addition of inhibitors. Octadecylphosphonic acid (ODPA) is an organic molecule which consists of a head phosphonic acid group that can chemically bond to the metal surface and a nonpolar portion that consists of an 18-member carbon chain. ODPA has been used for the formation of superhydrophobic surfaces and very good results have been reported $[22,23]$. In this study, the corrosion protection of AA 2024 modified with self-assembled films obtained by combining TEOS with ODPA (octadecylphosphonic acid) in a $0.05 \mathrm{~mol} \mathrm{~L}^{-1} \mathrm{NaCl}$ solution was investigated.

The films were prepared using solutions with different water contents. The volumetric ratios of TEOS/ethanol/water used were $4 / 90 / 6$ and $4 / 80 / 16$ and the corresponding films formed were denoted as 90TEOS and 80TEOS, respectively The corrosion behavior of ODPA-modified TEOS films was evaluated through electrochemical impedance spectroscopy (EIS) and potentiodynamic polarization tests complemented by FT-IR spectroscopy data. The wetting behavior was examined by contact angle measurements.

\section{MATERIALS AND METHODS}

The bare alloy samples were previously polished followed by immersion in $0.05 \mathrm{~mol} \mathrm{~L}^{-1}$ acetic acid solution for $5 \mathrm{~min}$, and then washed with distilled water and dried under a hot air stream[20]. The silanizing bath was prepared by mixing tetraethoxysilicate (TEOS, Sigma/ Aldrich), ethanol (Nuclear) and deionized water (18.3 $\left.\mathrm{M} \Omega \mathrm{cm}^{2}\right)$ in 4:90:6 (v/v) ratio and 4:80:16 (v/v) ratio. The silanizing bath with the inhibitor was prepared by dissolving different amounts of ODPA (octadecylphosphonic acid) in water corresponding to $6 \% \mathrm{v} / \mathrm{v}$ in a $4 \%$ $\mathrm{v} / \mathrm{v}$ TEOS and $90 \% \mathrm{v} / \mathrm{v}$ ethanol and $16 \% \mathrm{v} / \mathrm{v}$ in a $4 \% \mathrm{v} / \mathrm{v}$ TEOS and $80 \% \mathrm{v} / \mathrm{v}$ ethanol ,denoted as $90 \mathrm{TEOS}$ and 80 TEOS, respectively. Two concentration of phosphonic acid were tested in the baths: $5 \times 10^{-5}$ and $5 \times$ $10^{-4}$ mol. $\mathrm{L}^{-1}$ ODPA and the coatings were denoted as TEOS/ ODPA $10^{-5}$ and TEOS/ ODPA $10^{-4}$, respectively. The mixtures were stirred for $1 \mathrm{~h}$ at room temperature and kept for 3 days before use. It was employed polarization methods and electrochemical impedance spectroscopy, complemented by water contact angle (WCA) and FT-IR measurements. EIS were performed using an AUTOLAB PGSTAT 30/FRA 2 system. The working electrode was a AA2024-T3 panel with $1 \mathrm{~cm}^{2}$ of exposed area, a saturated calomel electrode (SCE) as reference electrode, to which all of the potentials are referred, and a Pt mesh as a counter electrode. EIS measurements were performed in the potentiostatic mode at OCP. The amplitude of the EIS perturbation signal was $10 \mathrm{mV}$, and the studied frequency range was $10^{5}$ to $10^{-2} \mathrm{~Hz}$. Experiments were performed at $25^{\circ} \mathrm{C}$, and a $0.05 \mathrm{~mol} \mathrm{~L}^{-1} \mathrm{NaCl}$ solution was employed. 
The analysis of surface hydrophobicity was done by contact angle measurements in water. The measurements were performed on a digital microscope Digital Blue brand, QXs model with the aid of Surf Tens software. The FT-IR analysis were performed with a Schimadzu spectrometer, model IR-Prestige-21. Spectra were collected by depositing the TEOS films on zinc selenate windows in a range of $4000-400 \mathrm{~cm}^{-1}$.

\section{RESULTS AND DISCUSSION}

Figure 1 shows the EIS plots for the bare alloy and for the alloy treated with 90TEOS and 80TEOS after immersion in $\mathrm{NaCl}$ for $24 \mathrm{~h}$ and $168 \mathrm{~h}$. The bare alloy and 90TEOS show similar plots, indicating that no beneficial effect was obtained. On increasing the exposure time up to $168 \mathrm{~h}$ the overall impedance decreased for the bare alloy and 90TEOS, followed by a slight decrease in the phase angle. The Bode spectra show a distinct behavior for the sample $80 \mathrm{TEOS}$ which, after $24 \mathrm{~h}$, presented two maximum phase angles close to $-35^{\circ}$, indicating that the film formed is very defective, leading to electrolyte uptake. After $168 \mathrm{~h}$, a third time constant appears at lower frequencies, indicating the development of corrosion activity.
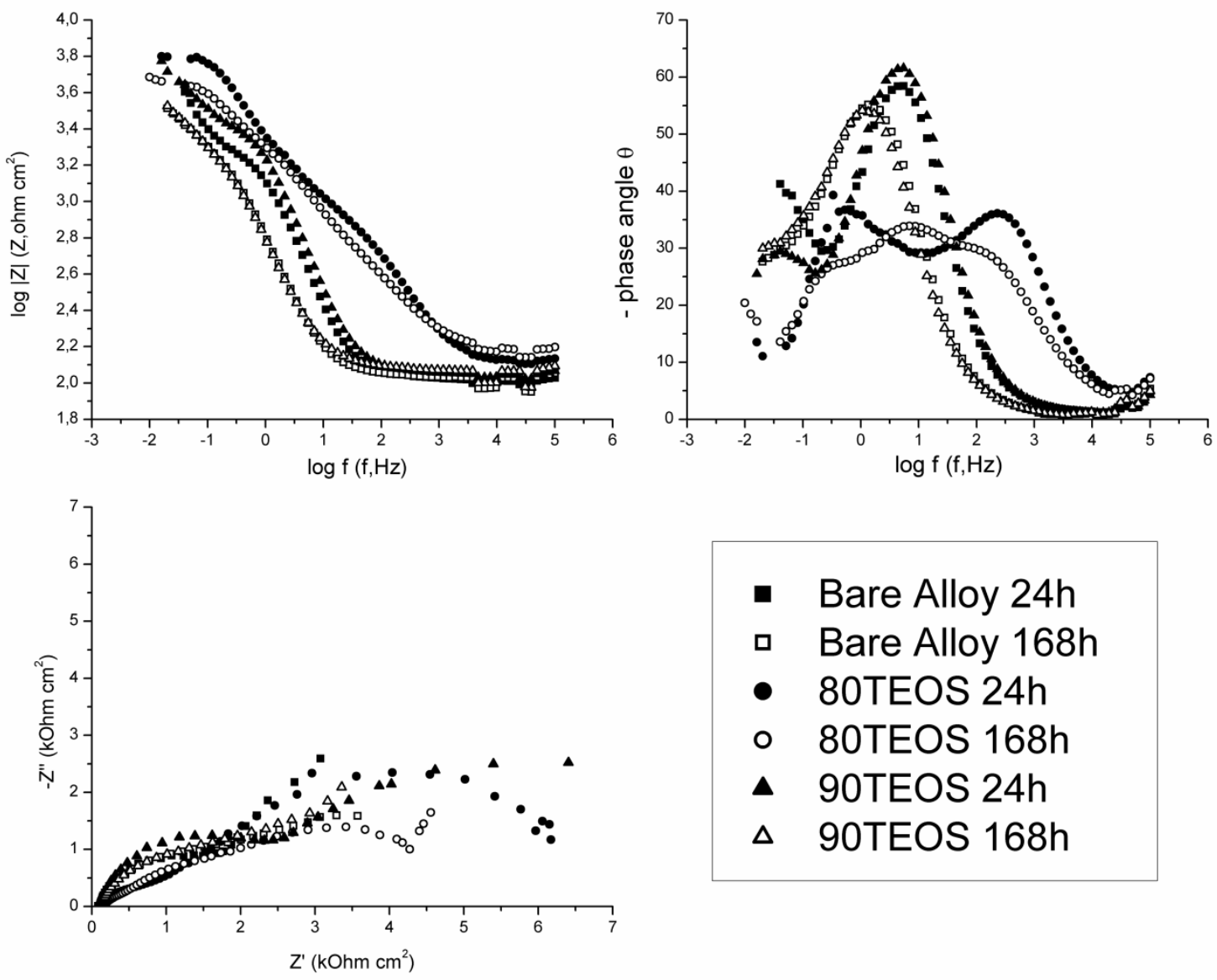

Figure 1: Effect of water content on EIS plots for AA2024 aluminum alloy in $0.05 \mathrm{~mol} / \mathrm{L} \mathrm{NaCl}$ at the open circuit potential after $24 \mathrm{~h}$ and $168 \mathrm{~h}$ of exposure.

The increased stability of the film produced with higher ethanol content (90TEOS) can be explained by the morphology of the films formed. According to Balbyshev and collaborators[24], when the mole ratio between water and alkoxide, denoted as $\mathrm{R}(\mathrm{R}=$ moles water/mole alkoxide), is approximately equal to 4 the formation of linear structures capable of forming thicker films is favored, when $\mathrm{R}$ is close to 10 the formation of circular siloxane chains gives rise to porous structures and when $\mathrm{R}$ is around to 20 a particulate three-dimensional structure is formed. The excess water accelerates the hydrolysis reactions and condensation reactions slow down, since water is produced under these conditions, resulting in a greater number of monomers being hydrolyzed before significant condensation reactions occur. Thus, the condensation of al- 
most completely hydrolyzed species favors the establishment of cyclic or branched siloxane bonds and the growth of particulate structures. Films obtained from 90TEOS have R values near to 4 while films obtained from 80TEOS have R values near to 12 .

Figure 2 shows the FT-IR spectra for 90TEOS and 80TEOS. The strong band at $3356 \mathrm{~cm}-1$ was attributed to the stretching of water and silanol O-H groups. The absorption at between $2974 \mathrm{~cm}-1$ and 2889 $\mathrm{cm}-1$ is attributed to the asymmetric and symmetric $\mathrm{C}-\mathrm{H}$ stretching vibrations of the ethoxy groups present in TEOS. The band at $1156 \mathrm{~cm}-1$ is associated with the $\mathrm{C}-\mathrm{H}$ rocking mode of SiOCH2CH3 ( $\delta$ rocking). At $1089 \mathrm{~cm}-1$ and $1049 \mathrm{~cm}-1$ the presence of two peaks can be observed, which are attributed to the asymmetric stretching ( $\gamma$ as) of Si-O(Si-O-Si). Finally, the bending mode of $\mathrm{Si}-\mathrm{OH}$ can be observed at $881 \mathrm{~cm}-1(\delta)[25$, 26].

Table 1 compares the $\gamma$ as $/ \delta$ and $\delta / \delta$ rocking values for the coatings obtained using different ethanol:water ratios. As can be seen in Table 1, on increasing the water content the $\mathrm{SIOH} / \mathrm{SICH} 2 \mathrm{CH} 3$ ratio increases and the SIOSI/SIOH ratio decreases, since hydrolysis is facilitated by the presence of water in the silanization bath.

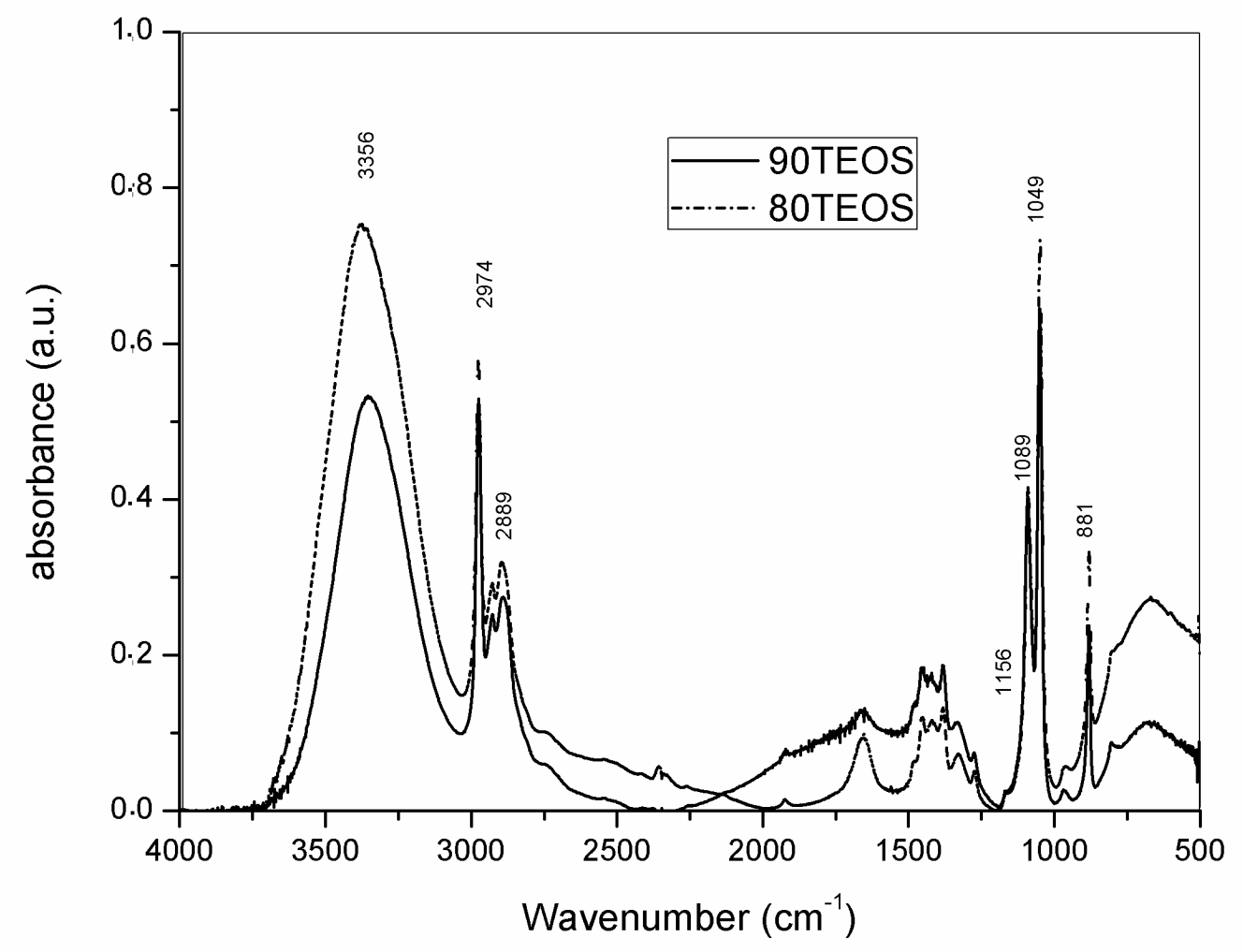

Figure 2: FT-IR spectra for 90TEOS and 80TEOS after 72h of hydrolysis.

Table 1: Ratio between the peak heights of the infrared bands obtained after $72 \mathrm{~h}$ of hydrolysis of $90 \mathrm{TEOS}$ and $80 \mathrm{TEOS}$.

\begin{tabular}{l|l|l}
\hline & $\gamma \mathrm{SiOSi} / \mathrm{SiOH}$ & $\delta \mathrm{SiOH} / \delta_{\text {rocking }} \mathrm{SiCH}_{2} \mathrm{CH}_{3}$ \\
\hline 90TEOS & 2.34 & 9.93 \\
\hline 80TEOS & 2.21 & 14.15 \\
\hline
\end{tabular}

The addition of ODPA to TEOS films was tested in order to provide protective features. The EIS spectra were obtained for 90TEOS and 80TEOS and for the films with the incorporation of $5 \times 10^{-5}$ and $5 \times 10^{-}$ ${ }^{4} \mathrm{~mol} \mathrm{~L} \mathrm{~L}^{-1}$ of ODPA, after immersion in $0.05 \mathrm{~mol} \mathrm{~L}^{-1} \mathrm{NaCl}$ for 24,48 and $168 \mathrm{~h}$. In the case of 80TEOS, the addition of $10^{-5}$ ODPA increased the impedance modulus for all immersion times tested (Figure 3 ). 

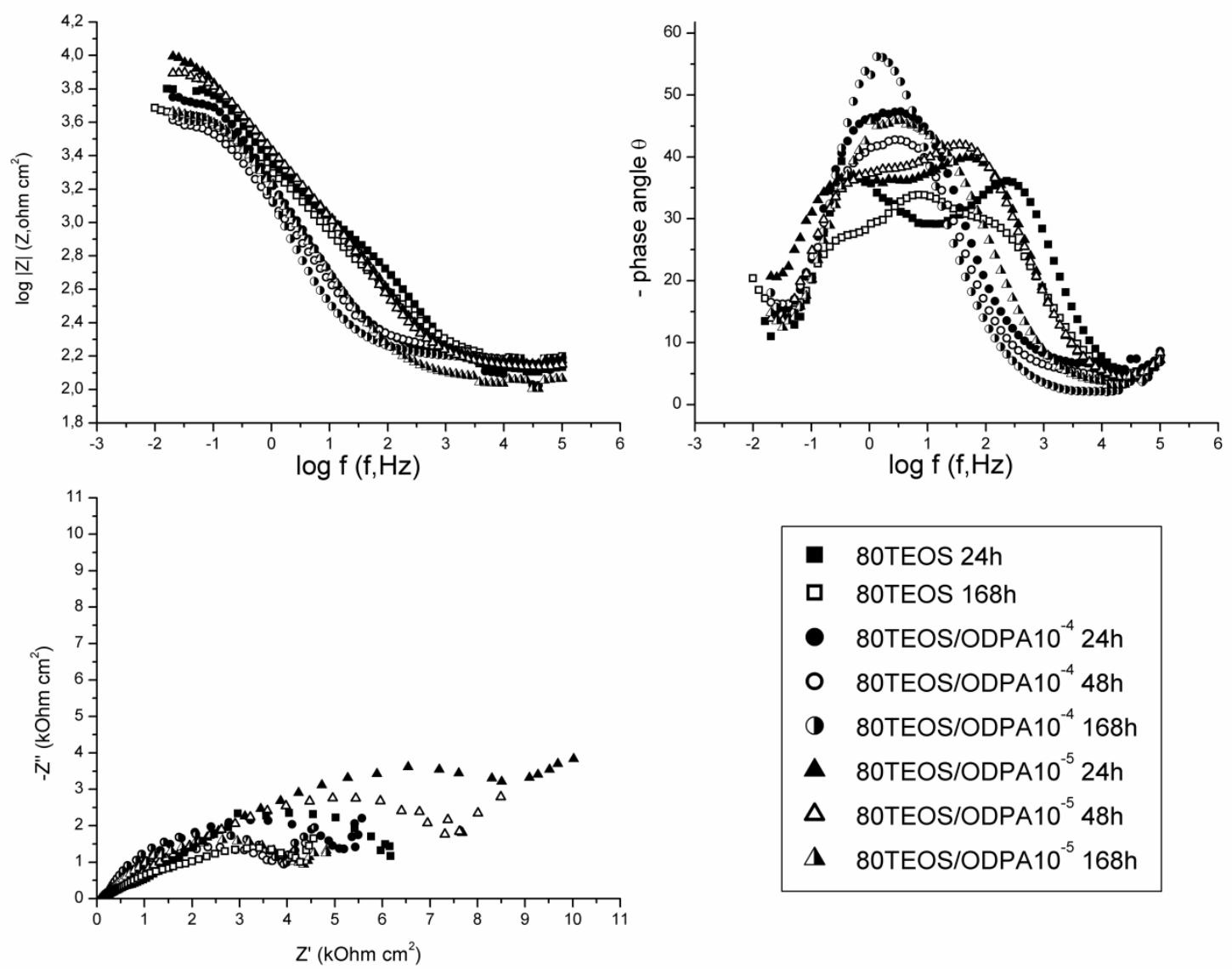

Figure 3: Effect of ODPA addition on EIS plots for 80TEOS in $0.05 \mathrm{~mol} / \mathrm{L} \mathrm{NaCl}$ at the open circuit potential after $24 \mathrm{~h}$, $48 \mathrm{~h}$ and $168 \mathrm{~h}$ of exposure.

In the case of 90 TEOS, after $24 \mathrm{~h}$ and $48 \mathrm{~h}$ of immersion the highest protection was obtained with $10^{-4}$ mol L ${ }^{-1}$ of ODPA. However, on increasing the exposure time to 7 days the protective action of the lowest ODPA concentration gave the best response (Figure $3 \mathrm{~b}$ ). The 90TEOS film with the addition of $5.00 \times 10^{-}$ ${ }^{5}$ mol L ${ }^{-1}$ ODPA presented the best performance considering all samples tested. Felhösi et al. [14] reported that a certain threshold concentration of phosphonate is necessary to ensure sufficient inhibition, this behavior being related to the surfactant nature of the phosphonic molecules. It has also been reported by Dalmoro et al. [21] that a high inhibitor concentration can hinder the synergistic effect of silane and phosphonic, affecting the degree of organization of the sol-gel network. Reports in the literature highlight the close relationship between the inhibitor concentration and the network stability, where a high content of inhibitor may lead to the formation of a fragile sol-gel layer with poor barrier properties [8,14,21,27]. 

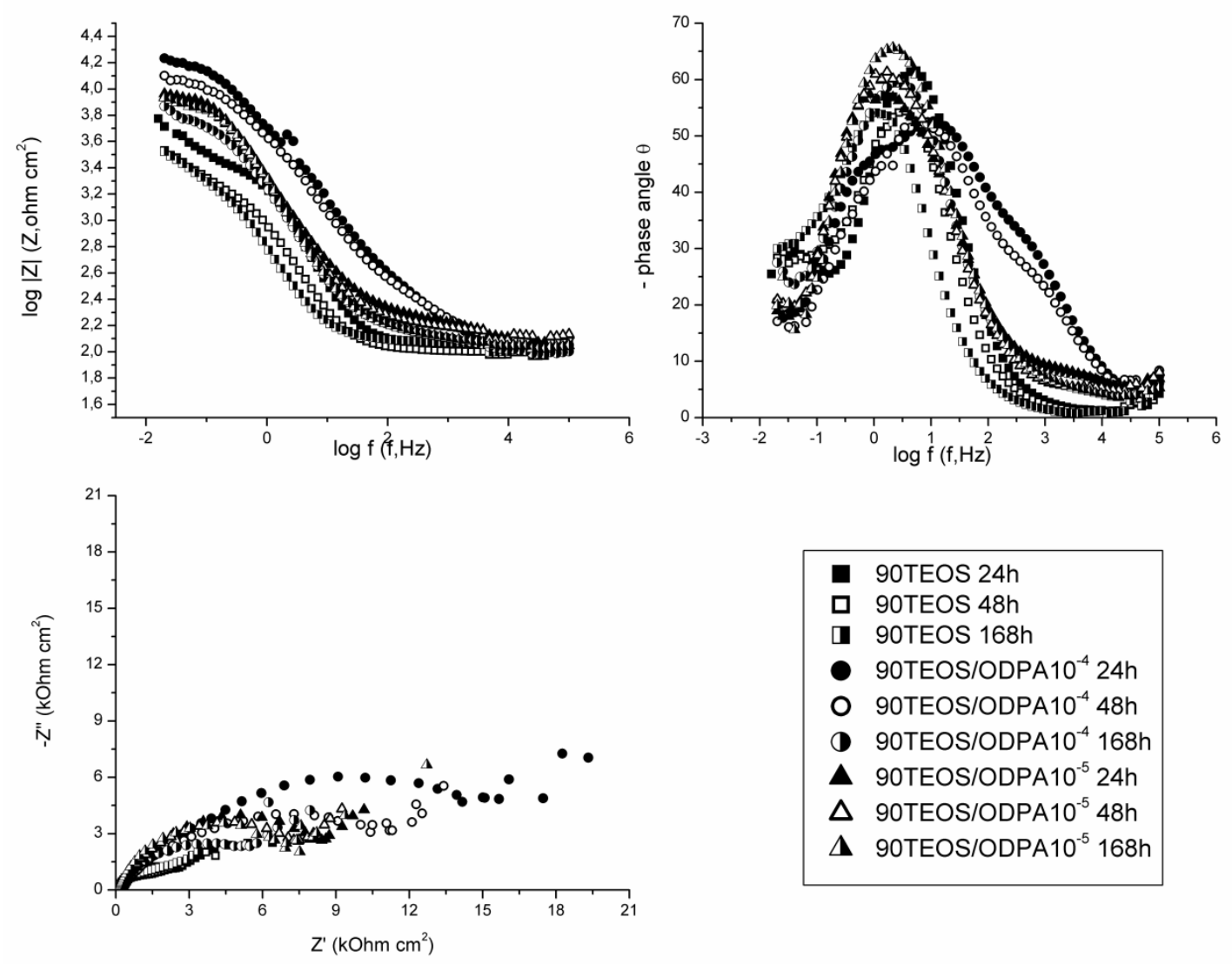

Figure 4: Effect of ODPA addition on EIS plots for 90 TEOS in $0.05 \mathrm{~mol} / \mathrm{L} \mathrm{NaCl}$ at the open circuit potential after $24 \mathrm{~h}$, $48 \mathrm{~h}$ and $168 \mathrm{~h}$ of exposure.

The evolution of the EIS spectra with immersion time (24 and $168 \mathrm{~h}$ ) in a $0.05 \mathrm{~mol} \mathrm{~L}^{-1} \mathrm{NaCl}$ solution at $25^{\circ} \mathrm{C}$, for AA2024-T3 coated with 90TEOS and 90TEOS/ODPA1 $0^{-5}$ was analyzed using an equivalent circuit. It can be seen that for 90TEOS the overall resistance decreased with time, which may be related to the onset of corrosion. In the case of the 90TEOS/ODPA $10^{-5}$ sample the overall impedance values remain more stable and the maximum phase angle is close to $-70^{\circ}$, suggesting that it is less porous and more protective than other samples. The experimental data were analyzed using an equivalent circuit (EC) with three time constants, given by $\mathrm{Rs}\left(\mathrm{CPE}_{\mathrm{HF}}\left[\mathrm{R}_{\mathrm{HF}}\left(\mathrm{CPE}_{\mathrm{LF}}\left[\mathrm{R}_{\mathrm{LF}} \mathrm{W}\right)\right]\right.\right.$, where $\mathrm{R}_{\mathrm{s}}$ is the ohmic resistance between the working and the reference electrode. For the bare alloy the time constant at high frequency $\left(\mathrm{R}_{\mathrm{HF}}\right.$ and $\left.\mathrm{CPE}_{\mathrm{HF}}\right)$ was associated with the internal oxide layer and that at lower frequency $\left(\mathrm{R}_{\mathrm{LF}}\right.$ and $\left.\mathrm{CPE} \mathrm{E}_{\mathrm{LF}}\right)$ was related to the external porous oxide layer. The capacitance associated with the internal oxide layer and external porous layer was replaced by a constant phase element (CPE) that describes a non-ideal capacitor when the phase angle is different from $-90^{\circ}$. The CPE impedance is attributed to the distributed surface reactivity, surface heterogeneity, roughness of the current and potential distribution, which in turn are related to the electrode geometry and the electrode porosity. A diffusional Warburg impedance (W) was included to account for the diffusion through the metal oxide layer on the bare alloy [28].

For the alloy treated with silanes, the time constant at higher frequencies $\left(\mathrm{R}_{\mathrm{HF}}\right.$ and $\left.\mathrm{CPE}_{\mathrm{HF}}\right)$ was related to the silane film resistance and capacitance and that at lower frequencies $\left(\mathrm{R}_{\mathrm{LF}}\right.$ and $\left.\mathrm{CPE}_{\mathrm{LF}}\right)$ to the resistance and capacitance of the interfacial layer. This interfacial layer is formed through the interaction of the $\mathrm{Al} \mathrm{OH}$ groups with $\mathrm{Si} \mathrm{OH}$ groups, forming Al-O-Si covalent bonds [27, 29]. The third time constant (W) in the lowest frequency range describes the electrochemical activity occurring inside the defects formed in the interfacial layers.

The fitting quality was assessed based on the error percentage associated with each circuit component, showing errors of less than $5 \%$. The simulated parameters are given in Table 2 . 
Table 2: Parameters of the silica films 90TEOS and 90TEOS/ODPA $10^{-5}$ after $24 \mathrm{~h}$ and $168 \mathrm{~h}$ of immersion in 0.05 $\mathrm{mol} \cdot \mathrm{L}^{-1} \mathrm{NaCl}$ obtained from the fitting of the experimental impedance spectra with the equivalent circuit.

\begin{tabular}{l|l|l|l|l|l|l}
\hline & \multicolumn{2}{l}{ BARE ALLOY } & \multicolumn{2}{l}{90 TEOS } & \multicolumn{2}{l}{90 TEOS/ODPA $10^{-5}$} \\
\cline { 2 - 7 } & $24 \mathrm{~h}$ & $168 \mathrm{~h}$ & $24 \mathrm{~h}$ & $168 \mathrm{~h}$ & $24 \mathrm{~h}$ & $168 \mathrm{~h}$ \\
\hline $\mathrm{Rs}\left(\Omega \cdot \mathrm{cm}^{2}\right)$ & 101.2 & 101.0 & 109.1 & 109.5 & 126.6 & 110.4 \\
\hline $\mathrm{R}_{\mathrm{HF}}\left(\Omega \cdot \mathrm{cm}^{2}\right)$ & 21.6 & 8.64 & 12.8 & 11.7 & 58.2 & 41.8 \\
\hline $\mathrm{CPE}_{\mathrm{HF}}\left(\mu \mathrm{F} \cdot \mathrm{cm}^{-2} \mathrm{~s}^{\mathrm{n}-1}\right)$ & 41.2 & 37.2 & 13.8 & 78.6 & 5.52 & 19.4 \\
\hline $\mathrm{n}_{\mathrm{HF}}$ & 0.91 & 0.77 & 0.78 & 0.76 & 0.84 & 0.82 \\
\hline $\mathrm{R}_{\mathrm{LF}}\left(\mathrm{k} \Omega \cdot \mathrm{cm}^{2}\right)$ & 1.19 & 2.07 & 2.25 & 1.97 & 9.55 & 8.93 \\
\hline $\mathrm{CPE}$ & 38.1 & 64.2 & 24.8 & 72.2 & 67.5 & 17.8 \\
\hline $\mathrm{n}_{\mathrm{LF}}\left(\mu \mathrm{F} \cdot \mathrm{cm}^{-2} \cdot \mathrm{s}^{\mathrm{n}-1}\right)$ & 0.86 & 0.79 & 0.90 & 0.84 & 0,83 & 0.86 \\
\hline $\mathrm{W}\left(\mathrm{k} \Omega \cdot \mathrm{cm}^{2} \cdot \mathrm{s}^{1 / 2}\right)$ & 1.41 & 0.58 & 1.17 & 0.71 & 0.69 & 0.64 \\
\hline
\end{tabular}

On increasing the immersion time $\mathrm{R}_{\mathrm{HF}}$ decreases and $\mathrm{CPE}_{\mathrm{HF}}$ increases for all samples, reflecting the film degradation, this effect being more pronounced for films without ODPA added. For the bare alloy and the TEOS film similar $\mathrm{R}_{\mathrm{LF}}$ and $\mathrm{CPE}_{\mathrm{LF}}$ values were observed for longer exposure times, which could be related to the onset of corrosion activity. The highly hydrophilic character of the TEOS film does not provide the alloy with effective protection [30]. The addition of ODPA allows the formation of a less porous and more protective film during immersion, as observed from the increased overall resistance and lower capacitance as compared to the 90TEOS samples. A previous study based on experimental analysis (FTIR and XPS) and theoretical calculations demonstrated that phosphonic groups can act as adhesion promoters for silane deposition on an aluminum surface, creating a more homogeneous and thinner coating. Conversely, according to the authors, in the absence of phosphonic molecules an irregular film was formed. Moreover, XPS results verified that the silanol groups are mainly located on the outside of the hybrid organic-inorganic film, whereas phosphorus and siloxane rings are found close to the metal surface [31].

The polarization curves for the bare alloy, 90TEOS and 90TEOS/ODPA $10^{-5}$ are shown in Figure 5. It can be seen that the $\mathrm{E}_{\text {corr }}$ shifts toward more positive values for the sample treated with 90TEOS/ODPA10 ${ }^{-5}$ even though the $i_{\text {corr }}$ values remained within the same order of magnitude (around $10^{-7} \mathrm{~A} \mathrm{~cm}^{-2}$ ). The curves indicate that in the absence of ODPA the dissolution processes occur earlier. 


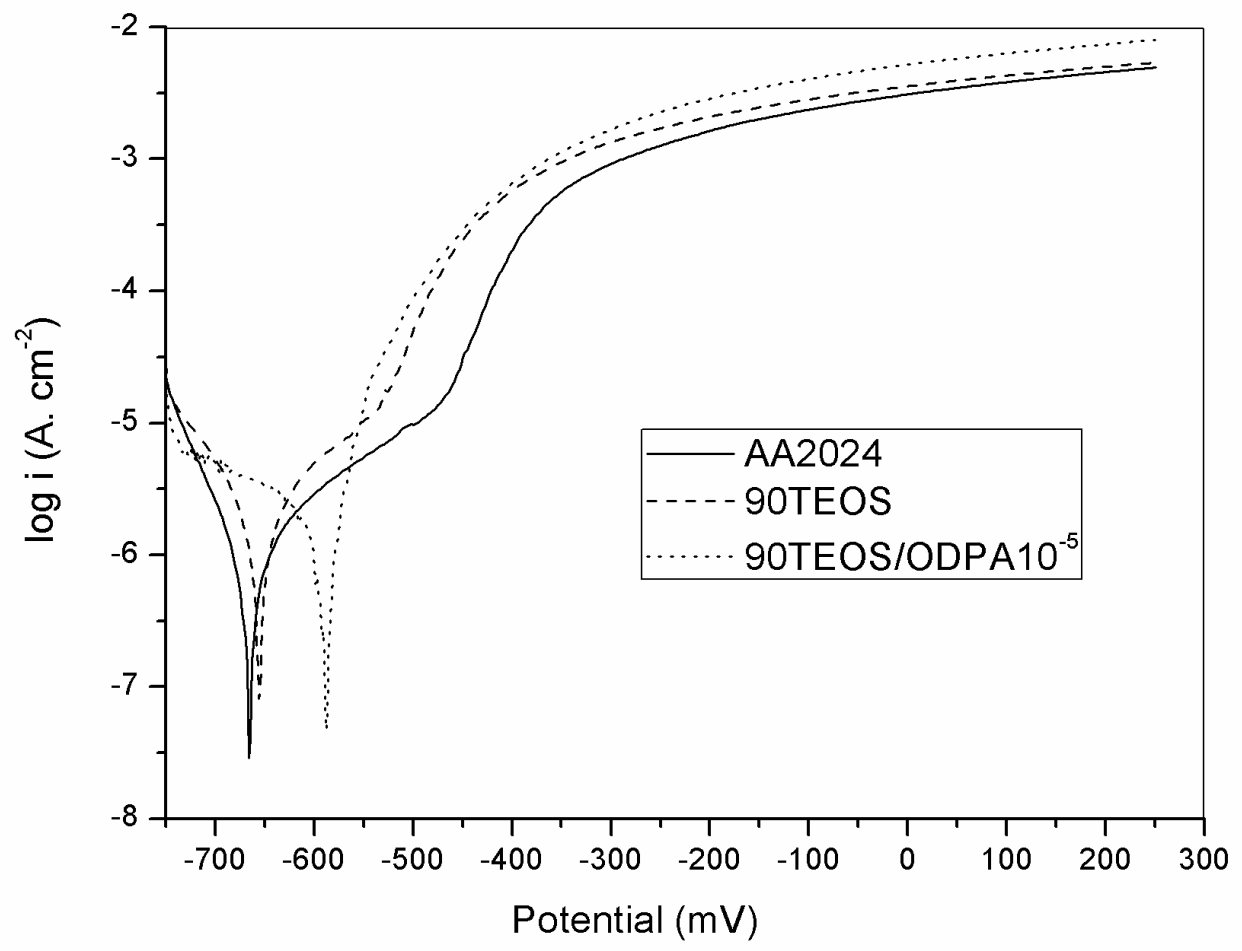

Figure 5: Polarization curves of AA2024 aluminum alloy, 90TEOS and 90TEOS/ODPA after 1h of exposure in 0.05 $\mathrm{mol} / \mathrm{L} \mathrm{NaCl}$.

The values for the contact angle (WCA) obtained for the samples coated with non-modified TEOS and with TEOS containing ODPA are presented in Table 3. A higher WCA is associated with better film hydrophobicity and therefore greater resistant to aqueous solution uptake. This feature was related to the presence of a long apolar carbon chain in the phosphonic acid structure [32].

Table 3: Contact angle values obtained on samples coated with TEOS and TEOS/ODPA.

\begin{tabular}{l|l}
\hline SAMPLE & CONTACT ANGLE $\left({ }^{\circ}\right)$ \\
\hline Bare alloy & $63.2 \pm 1.6$ \\
\hline 90TEOS & $70.2 \pm 1.5$ \\
\hline 90TEOS/ODPA $10^{-5}$ & $97.6 \pm 1.9$ \\
\hline 80TEOS & $71.4 \pm 0.1$ \\
\hline 80TEOS/ODPA $10^{-5}$ & $100.9 \pm 0.5$ \\
\hline
\end{tabular}

\section{CONCLUSIONS}

Modified TEOS films with the incorporation of the phosphonic acid ODPA were successfully prepared, thus effectively overcoming the typical limitations of TEOS films and providing a protective effect against the corrosion of the AA 2024 alloy. FTIR data showed that on increasing the water content the ratio between $\mathrm{SIOH} / \mathrm{SICH}_{2} \mathrm{CH}_{3}$ increases and the ratio between SIOSI/SIOH decreases, since hydrolysis is facilitated by the presence of water in the silanization bath. The EIS analysis indicated an improvement in the corrosion performance when phosphonic acid is added to films with $90 \%$ of water content at the optimal concentration $\left(5 \times 10^{-5} \mathrm{~mol} . \mathrm{L}^{-1}\right)$. The incorporation of ODPA into TEOS film showed a positive effect on the barrier properties of the sample due to the presence of a long carbon chain. The water contact angles showed that the addition of phosphonic acid enhances the hydrophobicity. 


\section{ACKNOWLEDGMENTS}

The authors are grateful to the CNPq and Capes Brazilian Agencies.

\section{BIBLIOGRAPHY}

[1] ÖRNEK, D., JAYARAMAN, A., WOOD, T.K., et al., "Pitting corrosion control using regenerative biofilms on aluminium 2024 in artificial seawater", Corrosion Scence, v. 43, n. 11, pp. 2121-2133, Nov. 2001.

[2] MOFFITT, C.E., WIELICZKA, D.M., YASUDA, H.K. "An XPS study of the elemental enrichment on aluminum alloy surfaces from chemical cleaning”, Surface and Coatings Technology, v. 137, n. 2, pp. 188196, Mar. 2001.

[3] PALANIVEL, V., HUANG, Y., VAN OOIJ, W.J. "Effects of addition of corrosion inhibitors to silane films on the performance of AA2024-T3 in a $0.5 \mathrm{M} \mathrm{NaCl}$ solution", Progress in Organic Coatings, v. 53, n. 2, pp. 153-168, June 2005.

[4] CABRAL, A.M., DUARTE, R.G., MONTEMOR, M.F., et al., "A comparative study on the corrosion resistance of AA2024-T3 substrates pre-treated with different silane solutions: Composition of the films formed”, Progress in Organic Coatings, v. 54, n. 4, pp. 322-331, December 2005.

[5] WANG, D., NI,Y., HUO, Q., et al., "Self-assembled monolayer and multilayer thin films on aluminum 2024-T3 substrates and their corrosion resistance study", Thin Solid Films, v. 471, n. 1, pp. 177-185, Jan. 2005.

[6] MAEGE, I., JAEHNE, E., HENKE, A., et al., "Self-assembling adhesion promoters for corrosion resistant metal polymer interfaces", Progress in Organic Coatings, v. 34, n. 4, pp. 1-12, Dec. 1998.

[7] TAMBORIM, S.M., MAISONNAVE, A.P.Z., AZAMBUJA, D.S., et al., "An electrochemical and superficial assessment of the corrosion behavior of AA 2024-T3 treated with metacryloxypropylmethoxysilane and cerium nitrate", Surface and Coatings Technology, v.202, n. 24, pp. 5991-6001, Aug. 2008.

[8] VOEVODIN, N.N., GREBASCH, N.T., SOTO, W.S., et al., "Potentiodynamic evaluation of sol-gel coatings with inorganic inhibitors”, Surface and Coatings Technology, v. 140, n. 1, pp. 24-28, May 2001.

[9] CORREA, P.S., MALFATTI, C.F., AZAMBUJA, D.S. "Corrosion behavior study of AZ91 magnesium alloy coated with methyltriethoxysilane doped with cerium ions", Progress in Organic Coatings, v. 72, n. 4, pp. 739-747, Aug. 2011.

[10] ROSERO-NAVARRO, N.C., PELLICE, S.A., DURAN A., et al.,"Effects of Ce-containing sol-gel coatings reinforced with $\mathrm{SiO}_{2}$ nanoparticles on the protection of AA2024”, Corrosion Science, v. 50, n. 5, pp. 1283-1291, May 2008.

[11] LEI, L., WANG, X., LIU, W., et al., "Surface evaluation and electrochemical behavior of cerium conversion coating modified with silane on magnesium alloy", Surface and Interface Analysis, v. 47, n. 4, pp. 466-473, Apr. 2015.

[12] IRIBARREN-MATEOS, J. I., BUJ-CORRAL, I., VIVANCOS-CALVET, J., et al., "Silane and epoxy coatings: A bilayer system to protect AA2024 alloy", Progress in Organic Coatings, v. 81, n. 1, pp. 47-57, Apr. 2015.

[13] JIANG, M., WU, L., HU, J., et al., "Silane-incorporated epoxy coatings on aluminum alloy (AA2024) Part 1: Improved corrosion performance”, Corrosion Science, v. 92, n. 1, pp. 118-126, Mar. 2015.

[14] FELHÖSI, I., KÁLMÁM, E., PÓCZIK, P. "Corrosion Protection by Self-Assembly”, Journal of Electrochemistry, v. 38, n. 3, pp. 230-237, Mar. 2002.

[15] KRAMOV, A.N., BALBYSHEV, V.N., KASTEN, L.S., et al., "Sol-gel coatings with phosphonate functionalities for surface modification of magnesium alloys", Thin solid Films, v. 514, n.1, pp. 174-181, Aug. 2006.

[16] ZHANG, X., CHEN, R., LIU, Y., et al., "Electrochemically generated sol-gel films as inhibitor containers of superhydrophobic surfaces for the active corrosion protection of metals", Journal of materials chemis$\operatorname{try} A$, v. 4, n.1, pp. 649-656, Dec. 2016.

[17] SU, H Y., CHEN, P L., LIN, C S. "Sol-gel coatings doped with organosilane and cerium to improve the properties of hot-dip galvanized steel”, Corrosion Science, v. 102, n.1, pp. 63-71, June 2016.

[18] ADHAMI, S., ATAPOUR, M., ALLAFCHIAN, A. R. "Corrosion protection of copper by silane sol-gel coatings" Journal of Sol-Gel Science and Technology, v. 74, n. 3, pp. 800-809, June 2015.

[19] LIAKOS, I.L., NEWMAN, R.C., MCALPINE, E., et al., "Comparative study of self-assembly of a 
range monofunctional aliphatic molecules on magnetrom-sputtered aluminium", Surface and Interface Analysis, v. 36, n. 4, pp. 347-354, Apr. 2004.

[20] DALMORO, V., SANTOS, J. H. Z., AZAMBUJA, D. S. "Corrosion behavior of AA2024-T3 alloy treated with phosphonate-containing TEOS", Journal of Solid State Electrochemistry, v. 16, n.1, pp 403-414, Jan. 2012.

[21] DALMORO, V., SANTOS, J. H. Z., ARMELIN, E., et al., "Phosphonic acid/silica-based films: A potential treatment for corrosion protection", Corrosion Science, v. 60, n. 1, pp. 173-180, July 2012.

[22] DAI, C., LIU, N., CAO, Y., et al., "Fast formation of superhydrophobic octadecylphosphonic acid (ODPA) coating for self-cleaning and oil/water separation”, Soft Matter, v.10, pp. 8116-8121, 2014.

[23] LAZAUSKAS, A., BALTRUSAITIS, J., GRIGALIŪNAS, V., et al., "Characterization of linear alkyl phosphonate self-assembled on perovskite substrate", Applied Surface Science, v. 344, pp.159-162, July 2015.

[24] DONLEY, M.S., MANTZ, R.A., KHRAMOV, A.N., et al., "The self-assembled nanophase particle (SNAP) process: a nanoscience approach to coatings", Progress in Organic Coatings, v. 47, n. 4, pp. 401415, Sept. 2003.

[25] FRANQUET, A., TERRYN, H., VEREECKEN, J. "Composition and thickness of non-functional organosilane films coated on aluminium studied by means of infra-red spectroscopic ellipsometry", Thin Solid Films, v. 441, o.1, pp. 76-84, Sept. 2003.

[26] COLTHUP, N.B., DALY, L.H., WIBERLEY, S.E. Introduction to Infrared and Raman Spectroscopy, 2ed., London, Academic Press, 1975.

[27] QUINET, M., NEVEU, B., MOUTARLIER, V., et al. "Corrosion protection of sol-gel coatings doped with an organic corrosion inhibitor: Chloranil”, Progress in Organic Coatings, v.58, n.1, pp. 46-53, Jan. 2007.

[28] WALTER, G.W. "A review of impedance plot methods used for corrosion performance analysis of painted metals", Corrosion Science, v. 26, no. 9, pp. 681-703, 1986.

[29] ZHELUDKEVICH, M.L., SERRA, R., MONTEMOR, M.F., et al., "Nanostructured sol-gel coatings doped with cerium nitrate as pre-treatments for AA2024-T3: Corrosion protection performance", Electrochimica Acta, v. 51, n. 2, pp. 208-217, Oct. 2005.

[30] DALMORO, V., SANTOS, J. H. Z., ARMELIN, E., et al., "A synergistic combination of tetraethylorthosilicate and multiphosphonic acid offers excellent corrosion protection to AA1100 aluminum alloy", Applied Surface Science, v. 273, pp. 758-768, May 2013.

[31] TORRAS, J., AZAMBUJA, D. S., WOLF, J. M., et al.,"How organophosphonic acid promotes silane deposition onto aluminum surface: A detailed investigation on adsorption mechanism", The Journal of Physical Chemistry C., v. 118, n. 31, pp. 17724-17736, July 2014.

[32] QU, J., NIE, D., LIU, C., et al., "Self-assembling behavior of TDPA molecules on inhomogeneous surface of 2024 aluminum alloy", Surface and Interface Analysis, v. 45, n. 9, pp. 1363-1371, Sept. 2013. 